\title{
Identifikasi Jenis Gangguan pada Jaringan Transmisi Menggunakan Metode Jaring Syaraf Tiruan
}

\author{
I Made Widiarsana $^{1}$, I Made Mataram², Yanu Prapto Sudarmojo ${ }^{3}$
}

\begin{abstract}
On transmission network often occur assorted disruption, as 1-phase short circuit to ground, phase-tophase short circuit, phase-to-earth short circuit, and symmetrical. The detection of the disruption can be done by using neural network method. Neural network consists of nonlinear element counter that each connected in parallel through load. Training process on this neural network consists of training process towards disruptions: 1-phase short circuit to ground, phase-to-phase short circuit, phase-to-earth short circuit, and symmetrical. Training process on this network transmission using 6 data input configuration, 10 hidden layer, 6 data target, and 6 output (6-10-6-6). The result show that the value of current and voltage for all kind of disruption on network transmission successfully resurrected, where the current and voltage output from training process will be saved and used as reference to determine the type of short circuit disruption that occur on network transmission.
\end{abstract}

Intisari- Pada jaringan transmisi sering terjadi berbagai macam jenis gangguan, antara lain gangguan hubung singkat satu phasa ke tanah, gangguan hubung singkat phasa ke phasa, gangguan antar phasa ke tanah dan gangguan simetris. Pendeteksian terhadap gangguan tersebut dapat dilakukan dengan metode jaring syaraf tiruan. Jaring syaraf tiruan terdiri dari sejumlah elemen penghitung tak linier yang masing-masing dihubungkan secara paralel melalui suatu pembobot. Proses training pada jaring syaraf tiruan ini terdiri dari proses pelatihan terhadap gangguan hubung singkat satu phasa ke tanah, gangguan hubung singkat phasa dengan phasa, gangguan hubung singkat antar phasa dengan tanah, dan gangguan simetris. Proses pelatihan pada jaringan transmisi ini menggunakan konfigurasi 6 data intput, 10 hidden layer, 6 data target, dan 6 output (6-10-6-6). Hasil pelatihan menunjukkan bahwa nilai arus dan tegangan gangguan untuk semua jenis gangguan pada jaringan transmisi berhasil di bangkitkan, dimana output berupa nilai tegangan dan arus dari proses pelatihan akan disimpan dan dijadikan sebagai refrensi untuk menentukan jenis gangguan hubung singkat yang terjadi pada jaringan transmisi. Data hasil simulasi jaringan transmisi dapat dikatakan normal saat mendekati nilai output atau sebaliknya ketika jaringan transmisi mengalami gangguan hubung singkat.

\footnotetext{
${ }^{1}$ Mahasiswa, Jurusan Teknik Elektro dan Komputer Fakultas Teknik Universitas Udayana, Jln WR. Supratman, Denpasar 80361 INDONESIA (tlp: 081237673611; fax: - ; e-mail: imadewidiarsana61@gmail.com)

${ }^{2,3}$ Dosen, Jurusan Teknik Elektro dan Komputer Fakultas Teknik Universitas Udayana, Jln. Kampus Bukit Jimbaran 80361 INDONESIA (telp: 0361-703315; fax: 0361-4321; e-mail: 2mataram@unud.ac.id, ${ }^{3}$ yanu.prapto@unud.ac.id
}

Kata Kunci- Jaringan transmisi, identifikasi, gangguan hubung singkat, jaring syaraf tiruan.

\section{PENDAHULUAN}

Sistem transmisi merupakan bagian penyaluran tenaga listrik dari generator station sampai pada distribution station yang menggunakan arus bolak balik (AC) sistem tiga phasa. Sistem tersebut memiliki beberapa kelebihan antar lain pembangkitan yang dilakukan lebih mudah, dapat menghasilkan medan magnet putar, pengubahan tegangannya lebih mudah dan daya yang disalurkan lebih besar dengan nilai sesaat yang konstan.

Pada jaringan transmisi sering terjadi berbagai macam jenis gangguan, antara lain gangguan hubung singkat satu phasa ke tanah, gangguan hubung singkat phasa ke phasa, gangguan antar phasa ke tanah dan gangguan simetris. Pendeteksian terhadap gangguan tersebut dapat dilakukan dengan metode jaring syaraf tiruan. Penggunaan metode jaring syaraf tiruan ini dipilih karena dapat mendeteksi jenis gangguan yang terjadi secara akurat dan cepat pada sistem saluran transmisi [1]. Beberapa kelebihan yang dimiliki oleh jaring syaraf tiruan yaitu, memiliki kemampuan belajar terhadap kesalahan yang terjadi, bersifat fleksibel terhadap perubahan yang terjadi pada suatu lingkungan, memiliki kemampuan perhitungan secara pararel, dan dapat menyelesaikan suatu permasalahan yang lebih kompleks yang tidak dapat diselesaikan dengan metode konvensional [2].

Mekanisme jaring syaraf tiruan (JST) menyerupai sistem syaraf makhluk hidup. Jaring syaraf tiruan memiliki satu atau lebih neuron yang berfungsi sebagai elemen pengolah dari beberapa masukan pada dendrirt. Sebuah neuron berperan untuk mengolah masukan beserta bobotnya. Selain itu juga berfungsi untuk transfer yang bertanggung jawab pada pengaliran luarnya ke neuron pengolah lain [3].

\section{SALURAN TRANSMISI DAN JARING SYARAF TIRUAN}

\section{A. Saluran Transmisi}

Saluran transmisi memiliki peranan yang sangat penting dalam mendistribusikan tenaga listrik dari generator station sampai distribution station [4]. Tenaga listrik dialirkan melalui suatu bahan konduktor dalam saluran transmisi listrik. Berdasarkan besaran kapasitas tegangan yang disalurkan, saluran transmisi dibedakan menjadi [5]:

1. Saluran transmisi tegangan rendah (380V, 220V)

2. Saluran transmisi tegangan menengah $(20 \mathrm{kV})$

3. Saluran transmisi tegangan tinggi $(70 \mathrm{kV}, 150 \mathrm{kV}, 225 \mathrm{kV})$

4. Saluran transmisi tegangan ekstra tinggi $(275 \mathrm{kV}, 500 \mathrm{kV})$

5. Saluran transmisi tegangan ultra tinggi $(750 \mathrm{kV})$ 


\section{B. Gangguan Hubung Singkat}

Gangguan hubung singkat adalah suatu keadaan ketidaknormalan yang terjadi pada sistem jaringan transmisi listrik, dimana ketidaknormalan yang terjadi dalam sistem jaringan transmisi listrik mengakibatkan mengalirnya arus yang tidak seimbang dalam sistem jaringan transmisi tiga phasa. Gangguan hubung singkat berdasarkan kesimetrisannya dibedakan menjadi gangguan asimetris dan gangguan simetris. Gangguan asimetris terdiri dari gangguan hubung singkat satu phasa ke tanah, gangguan antar phasa, gangguan antar phasa ke tanah, sedangkan gangguan simetris terdiri dari gangguan simetris. Gangguan simetris adalah gangguan hubung singkat yang terjadi pada semua phasanya sehingga menyebabkan arus maupun tegangan pada setiap phasanya tetap bernilai seimbang setelah terjadi gangguan [6].

\section{Backpropagation Neural Network}

Metode jaring syaraf tiruan backpropagation adalah metode algoritma pembelajaran terawasi, dimana metode backpropagation digunakan untuk mengubah nilai bobot yang terhubung dengan sebuah neuron pada lapisan hidden layer menggunakan perceptron dengan banyak lapisan. Neural network backpropagation terdiri dari terdiri dari satu atau lebih unit layer pemroses. Layer input yang berfungsi menerima input dari luar adalah unit layer paling awal. Hidden layer adalah layer yang terdapat setelah lapisan input. Output layer adalah layer yang paling akhir [7]. Struktur jaring syaraf tiruan backpropagation dapat dilihat dalam gambar 1 .

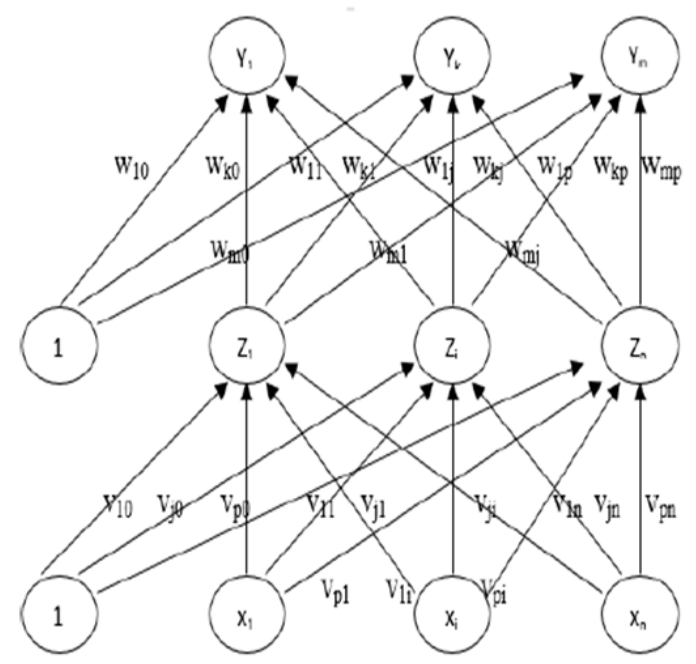

Gambar 1: Arsitektur jaring syaraf tiruan backpropagation [8]

Algoritma pelatihan jaring syaraf tiruan backpropagation terdiri dari dua langkah yaitu langkah perambatan maju dan langkah perambatn mundur. Langkah perambatan maju dimulai dengan memberikan sebuah masukan ke dalam lapisan layer input. Pola masukan yang diberikan berupa nilai aktivasi terhadap unit-unit masukan. Langkah perambatan mundur merupakan proses perhitungan nilai galat dan mengubah nilai bobot pada semua interkoneksinya. Perhitungan pada langkah perambatan mundur dimulai dari lapisan output layer dan mundur sampai pada lapisan input layer. Hasil output dari perambatan maju akan dibangdingkan dengan hasil keluaran atau taget yang diinginkan [9].

\section{METODE ANALISA DATA DAN PEMODELAN SISTEM}

Penelitian ini bertempat di Program Studi Teknik Elektro Fakultas Teknik Universitas Udayana kampus sudirman dengan tujuan mensimulasikan deteksi jenis gangguan yang terjadi pada jaringan transmisi dan waktu pelaksanaannya dimulai pada Januari 2016.

Referensi [10] merupakan sumber data dari penelitian ini, dimana pada jurnal tersebut data yang digunakan dengan sistem $400 \mathrm{kV}$, yang terdiri dari dua generator $11 \mathrm{kV}$ yang masing-masing terletak di kedua ujung jaringan transmisi bersama dengan simulator tiga phasa yang digunakan untuk mensimulasikan lokasi gangguan pada jaringan transmisi.

Alur identifikasi jenis gangguan pada jaringan transmisi dengan menggunakan metode jaring syaraf tiruan dapat dilihat pada gambar 2 .
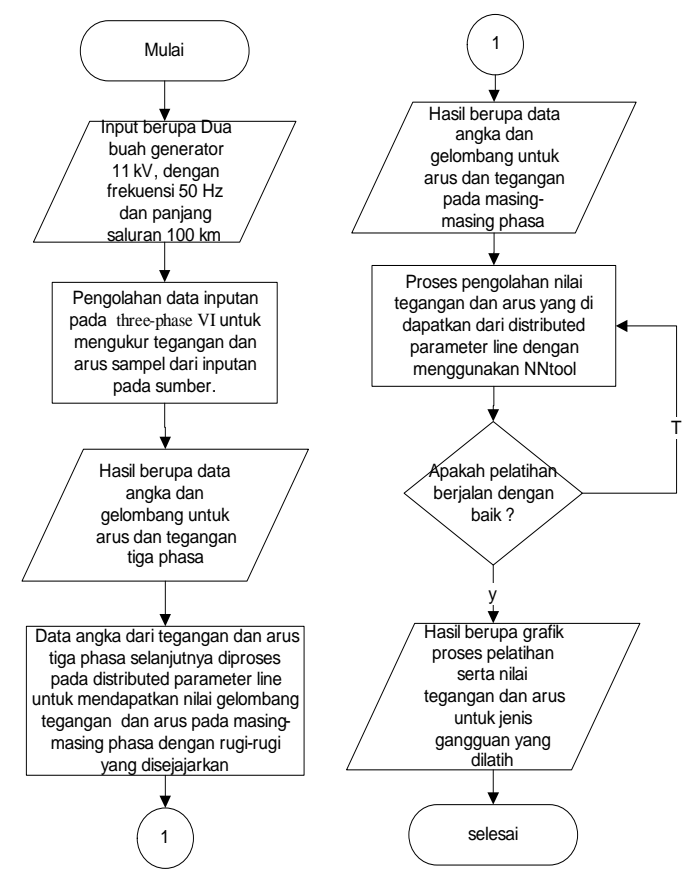

Gambar 2: Flowchart diagram alur identifikasi gangguan jaringan transmisi

Simulasi yang dilakukan pada Simulink MATLAB dengan desain pemodelan yang dirancang merupakan sistem jaringan tiga phasa. Model simulasi yang dirancang pada simulink $M A T L A B$ dapat dilihat dalam gambar 3. 


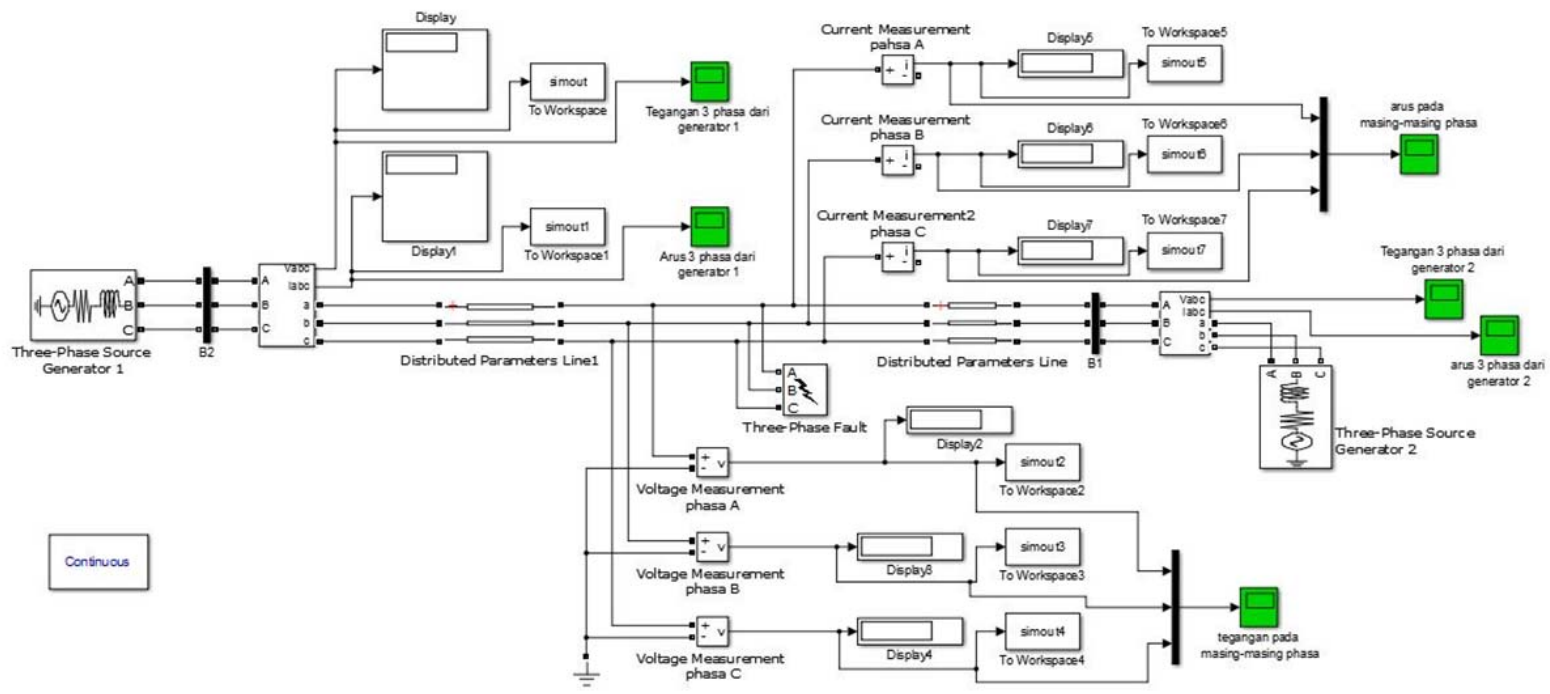

Gambar 3: Rangkaian Simulasi Gangguan

\section{HASIL DAN PEMBAHASAN}

\section{A. Analisa dan Pembahasan}

Proses pelatihan terhadap identifikasi jenis gangguang pada jaringan transmisi dengam menggunakan metode jaring syaraf tiruan dimulai dengan pembuatan rangkaian simulasi gangguan yang akan digunakan. Data yang digunakan sebagai input awal pada pada simulasi adalah dua buah generator 11 $\mathrm{kV}$ yang terletak pada kedua ujung simulasi dengan frekuensi $50 \mathrm{~Hz}$ dan panjang saluran $100 \mathrm{~km}$. Kemudian akan dilakukan pengujian terhadap simulasi, setelah dilakukan pengujian terhadap simulasi akan didapatkan data tegangan dan arus pada masing-masing phasa. Data tersebut kemudian akan digunakan sebagai input dalam proses pelatihan identifikasi jenis gangguan menggunakan metode jaring syaraf tiruan dengan menggunakan nntool pada matlab.

konfigurasi yang digunakan pada proses pelatihan adalah 6 data input, 10 hidden layer, 6 data target, dan 6 data output. Konfigurasi yang digunakan pada proses pelatihan dapat dilihat dalam gambar 4 .

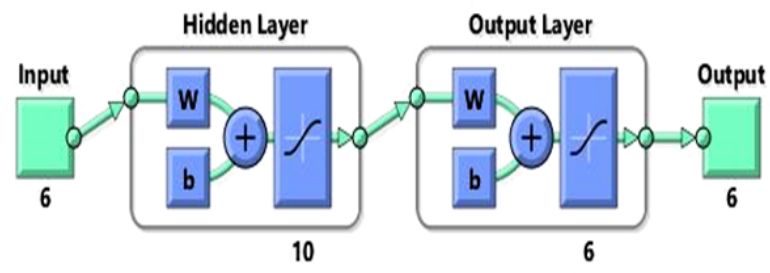

Gambar 4: Konfigurasi yang digunakan dalam proses pelatihan

\section{B. Proses Pembangkitan Gelombang Tegangan dan Arus}

Proses pembangkitan gelombang tegangan dan arus gangguan pada jaringan transmisi bertujuan untuk mendapatkan nilai tegangan dan arus pada masing-masing

I Made Widiarsana: Identifikasi Jenis Gangguan pada Jaringan ... phasa. Nilai tegangan dan arus pada masing-masing phasa ini akan digunakan sebagai nilai input dan target dalam proses pelatihan.

1) Pada Keadaan Normal: Proses pembangkitan pada keadaan normal bertujuan untuk menghasilkan data yang digunakan sebagai acuan dalam menentukan ada tidaknya ganguan hubung singkat pada jaringan transmisi.

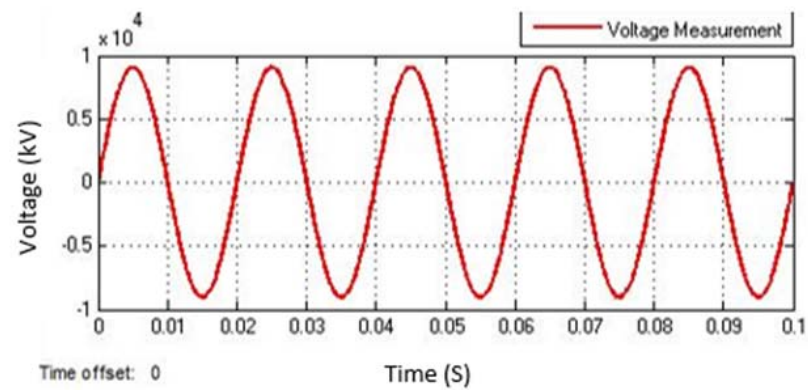

(a) Gelombang Tegangan Phasa A

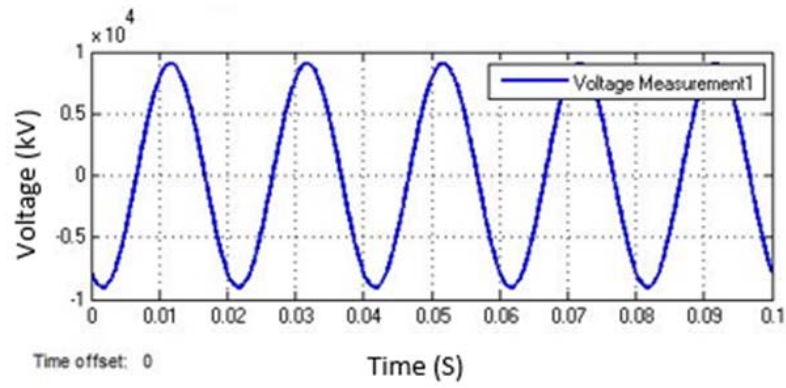

(b) Gelombang Tegangan Phasa B

p-ISSN:1693 - 2951; e-ISSN: 2503-2372 


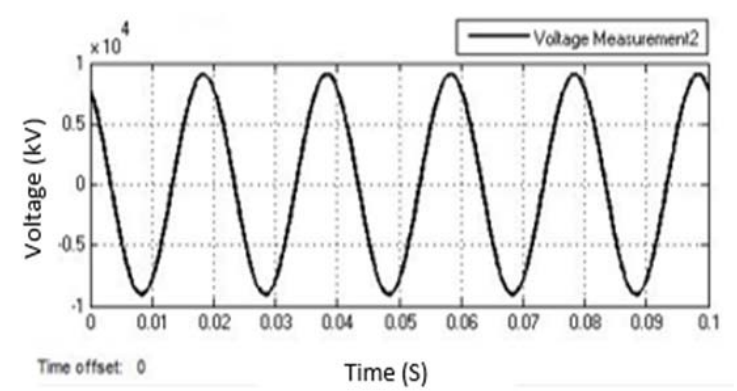

(c) Gelombang Tegangan Phasa C

Gambar 5: Gelombang tegangan masing-masing phasa saat keadaan normal

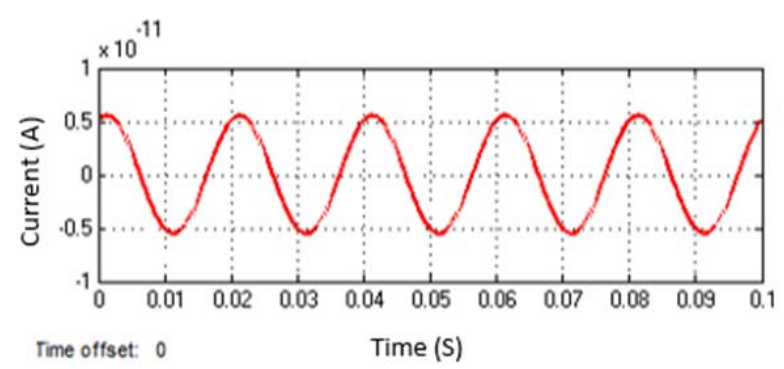

(a) Gelombang Arus Phasa A

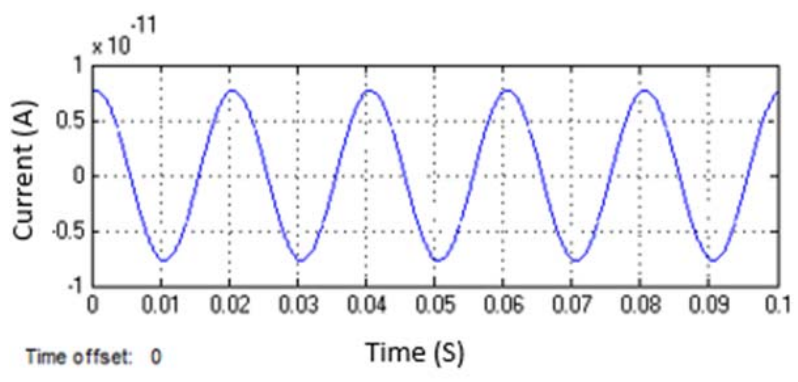

(b) Gelombang Arus Phasa B

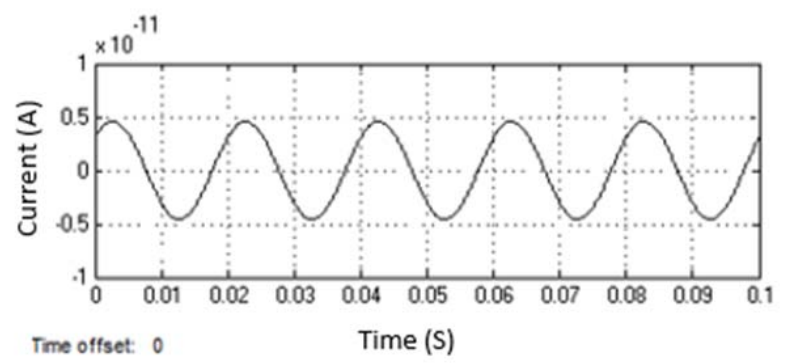

(c) Gelombang Arus Phasa C

Gambar 6: Gelombang arus masing-masing phasa saat keadaan normal

2) Gangguan Satu Phasa ke Tanah: Proses pembangkitan gelombang tegangan dan arus pada gangguan satu phasa ke tanah, dimana gangguan yang terjadi diatur pada phasa A dan memperoleh hasil sebagai berikut.

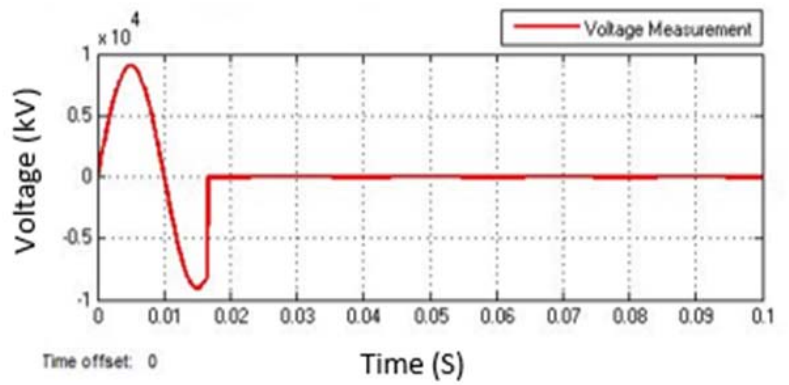

Gambar 7: Gelombang tegangan phasa A saat gangguan hubung singkat satu phasa ke tanah

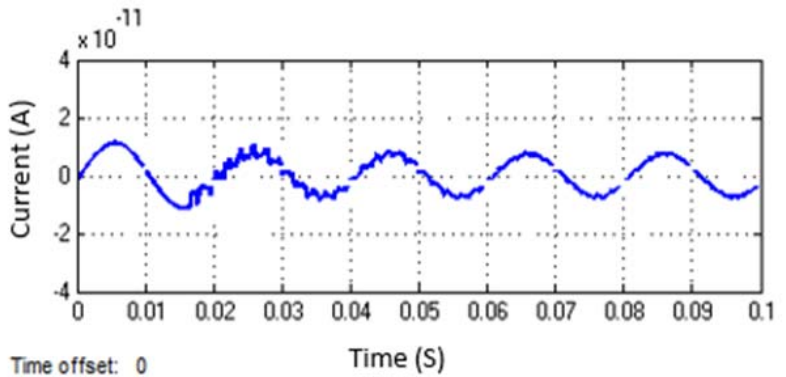

Gambar 8: Gelombang arus phasa B saat gangguan hubung singkat satu phasa ke tanah

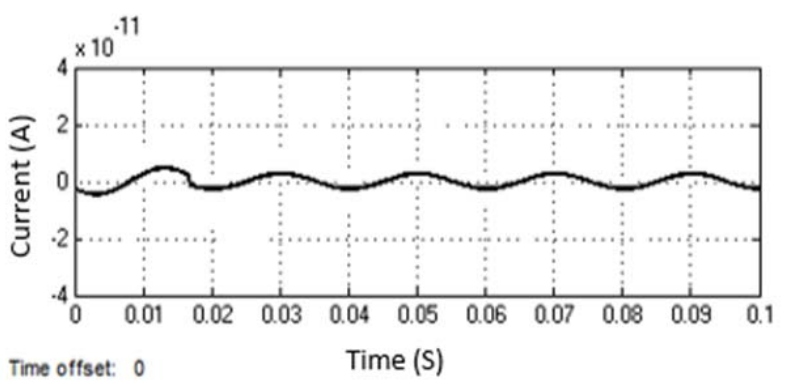

Gambar 9: Gelombang arus phasa C saat gangguan hubung singkat satu phasa ke tanah

3) Gangguan antar Phasa ke Tanah: Proses pembangkitan gelombang tegangan dan arus pada gangguan antar phasa ke tanah, gangguan antar phasa ke tanah yang terjadi diatur pada phasa A dan phasa B, dimana hasil yang diperoleh adalah sebagai berikut.

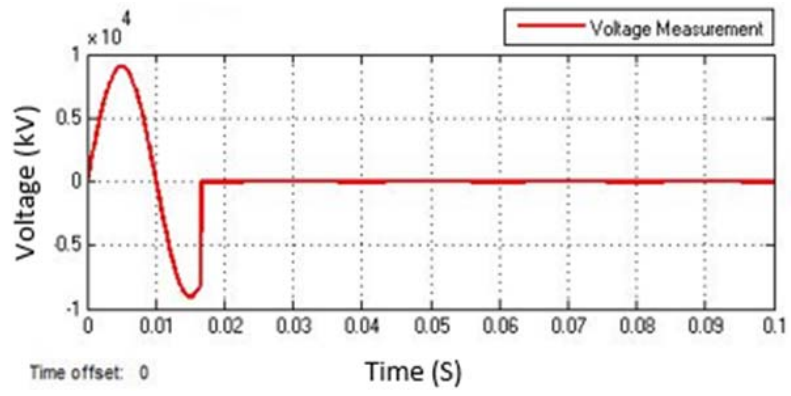

(a) Gelombang Tegangan Phasa A 


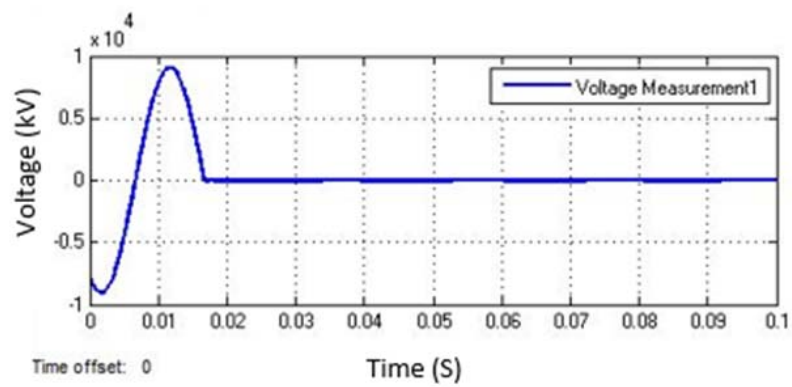

(b) Gelombang Tegangan Phasa B

Gambar 10: Gelombang tegangan phasa A dan B saat gangguan antar phasa ke tanah

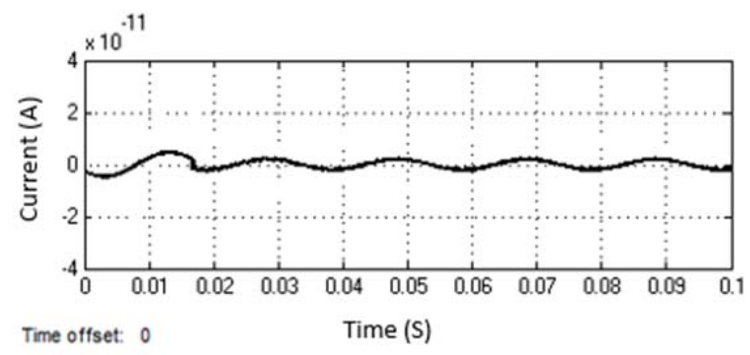

Gambar 11: Gelombang arus phasa C saat gangguan antar phasa ke tanah

4) Gangguan Antar Phasa: Proses pembangkitan gelombang tegangan dan arus pada gangguan $\mathrm{t}$ antar phasa, gangguan yang terjadi diatur pada phasa A dan phasa B tanpa dihubungkan ke tanah, dimana hasil yang diperoleh adalah sebagai berikut

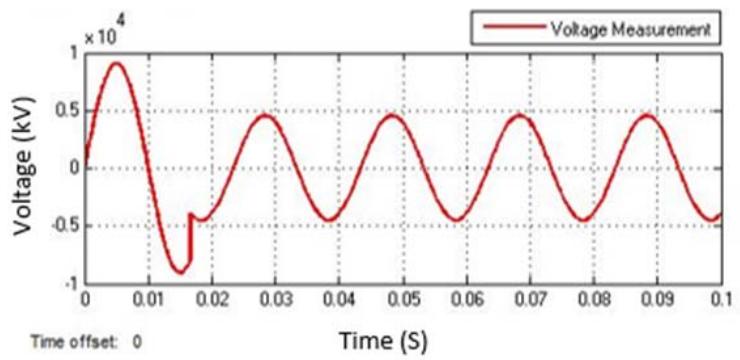

(a) Gelombang Tegangan Phasa A

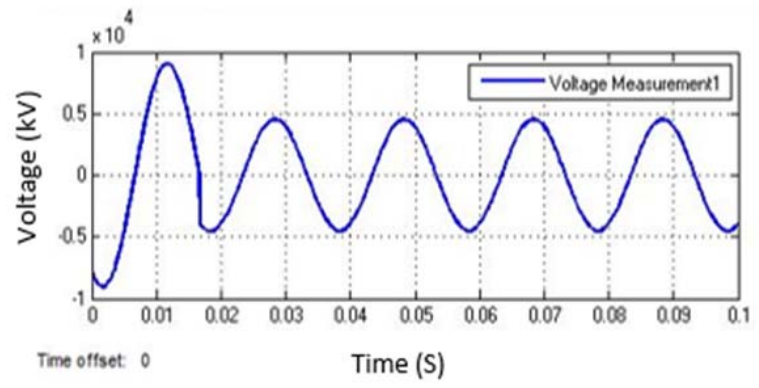

(b) Gelombang Tegangan Phasa B

Gambar 12: Gelombang tegangan phasa A dan phasa B saat gangguan antar phasa

I Made Widiarsana: Identifikasi Jenis Gangguan pada Jaringan ...

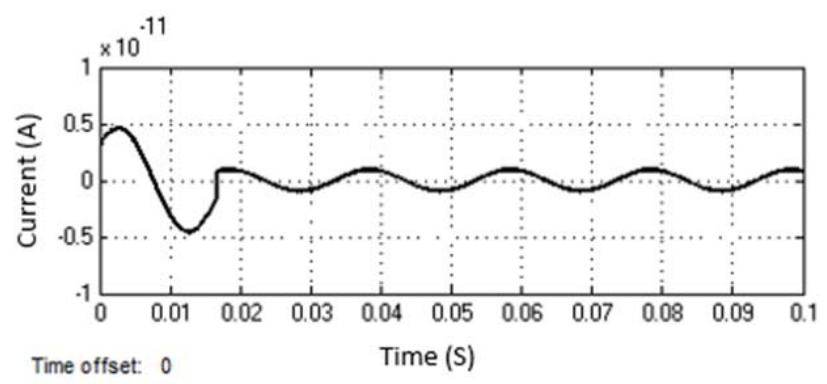

Gambar 13: Gelombang arus phasa C saat gangguan antar phasa

5) Gangguan simetris: Proses pembangkitan gelombang tegangan dan arus pada gangguan simetris, gangguan yang terjadi diatur pada phasa A, phasa B dan phasa C, dimana hasil yang diperoleh adalah sebagai berikut.

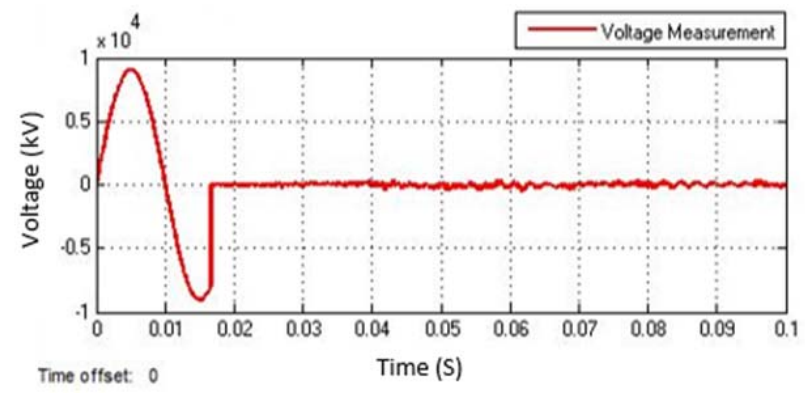

(a) Gelombang Tegangan Phasa A

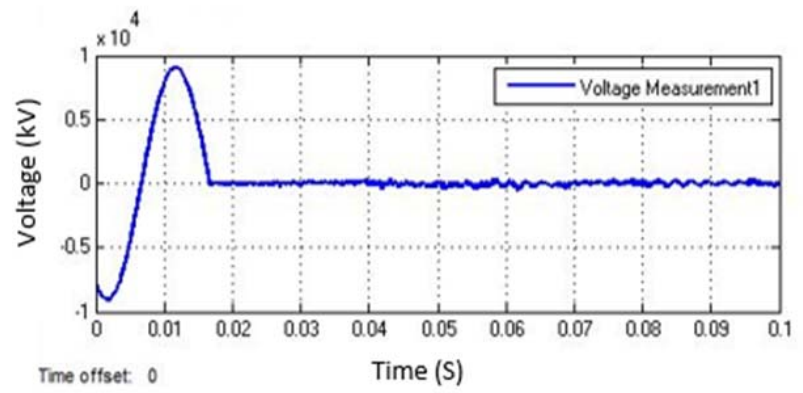

(b) Gelombang Tegangan Phasa B

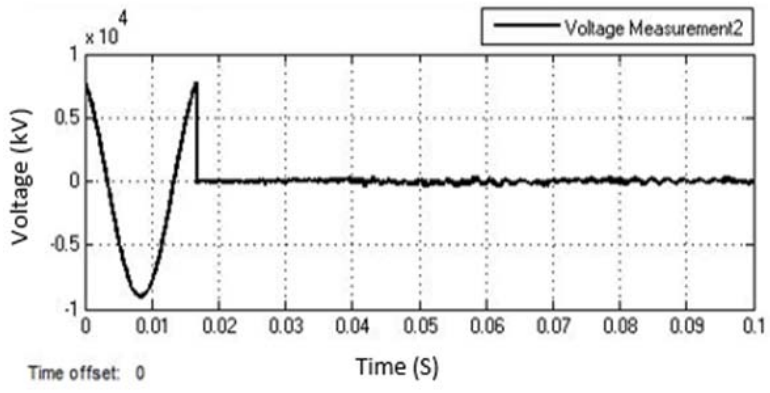

(c) Gelombang Tegangan Phasa C

Gambar 14: Gelombang tegangan phasa A, phasa B dan phasa C saat gangguan simetris

p-ISSN:1693 - 2951; e-ISSN: 2503-2372 


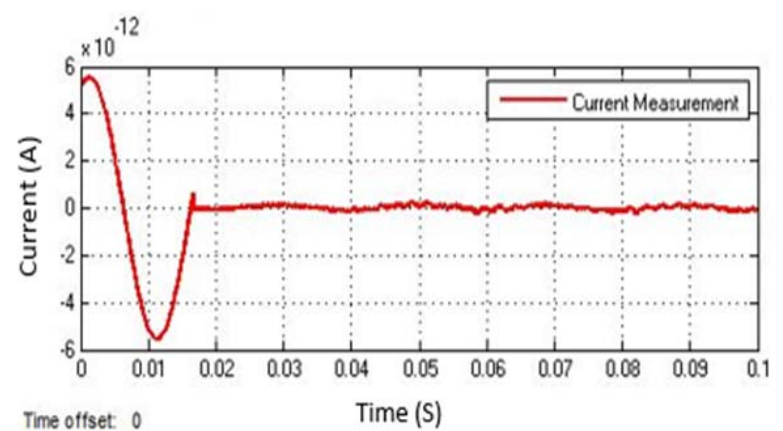

(a) Gelombang Arus Phasa A

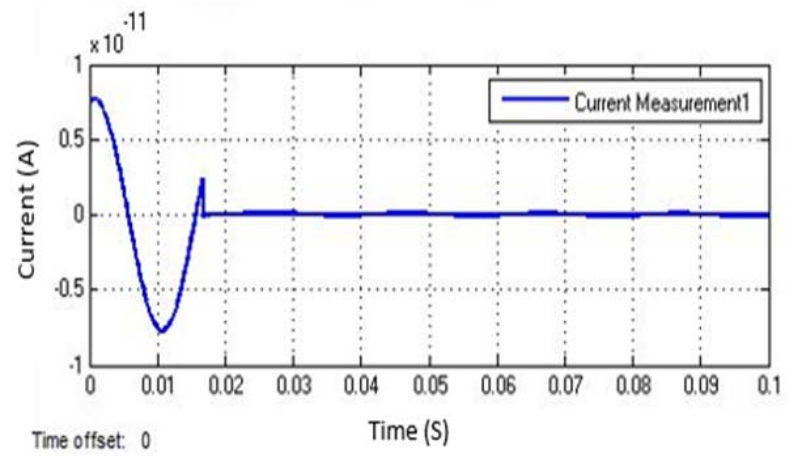

(b) Gelombang Arus Phasa B

Gambar 15: Gelombang arus phasa A dan phasa B saat gangguan simetris

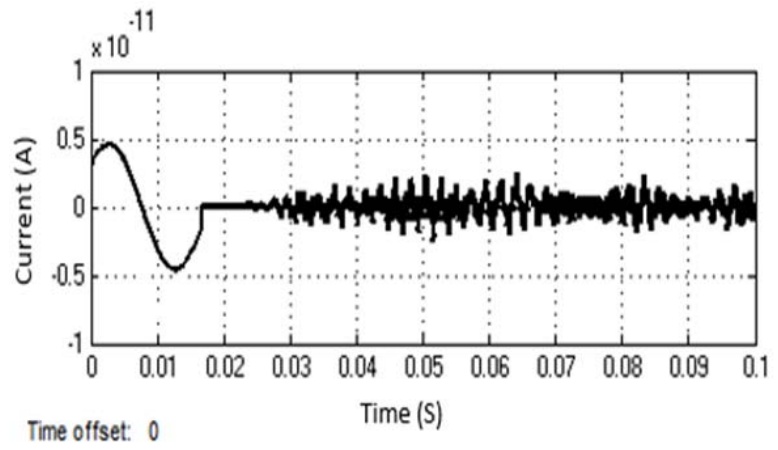

Gambar 16: Gelombang arus phasa C saat gangguan simetris

\section{Proses Identifikasi Jenis Gangguan Pada Jaringan Transmisi Menggunakan Jaring syaraf tiruan}

Identifikasi jenis gangguan pada jaringan tansmisi menggunakan metode jaring syaraf tiruan dilakukan dengan proses training atau pelatihan. Proses training ini terdiri dari proses pelatihan terhadap gangguan satu phasa ke tanah, gangguan antar phasa, gangguan antar phasa dengan tanah, dan gangguan simetris. Proses pelatihan pada jaringan transmisi ini menggunakan masukan dua buah generator three-phase source, dimana tegangan input pada setiap generator adalah sebesar $11 \mathrm{kV}$ dengan frekuensi $50 \mathrm{~Hz}$.

\section{Proses Pelatihan Dengan Metode Jaring syaraf tiruan Pada Keadaan Normal}

Proses pelatihan pada keadaan normal bertujuan untuk menghasilkan data yang digunakan sebagai acuan dalam menentukan ada tidaknya gangguan hubung singkat pada jaringan transmisi.

Grafik performance pada proses pelatihan diperoleh dari hasil perbandingan antara nilai mean squared error (MSE) dengan epoch. Epoch merupakan jumlah iterasi yang dilakukan atau dihasilkan dari proses pelatihan. Hasil dari pelatihan ditunjukkan dengan warna biru, hasil validasi ditunjukkan dengan warna hijau, hasil test ditunjukkan dengan warna merah, dan nilai best atau nilai terbaik dari hasil performance ditunjukkan dengan garis titik-titik. Hasil performance terbaik pada saat keadaan normal diperoleh pada saat epoch ke 238 dari 244 epoch dengan nilai best validation performance 8.7591. Grafik performance pada proses pelatihan saat keadaan normal dapat dilihat dalam gambar 17.

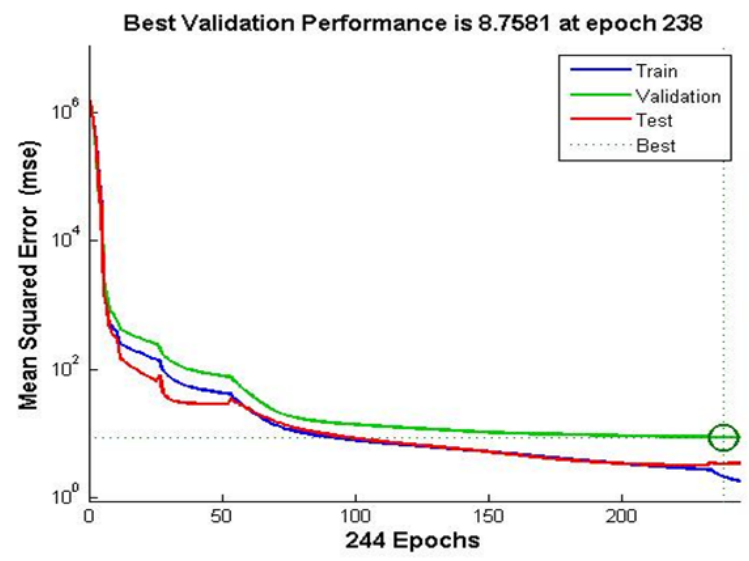

Gambar 17: Hasil performance pada saat keadaan normal

\section{E. Proses Pelatihan Dengan Metode Jaring syaraf tiruan Pada Gangguan Satu Phasa ke Tanah}

Proses pelatihan gangguan satu phasa ke tanah pada jaringan transmisi menggunakan metode jaring syaraf tiruan, dimana gangguan yang terjadi diatur pada phasa A dan hasilnya kemudian di analisa sebagai berikut.

Grafik performance pada proses pelatihan gangguan satu phasa ke tanah diperoleh dari hasil perbandingan antara nilai mean squared error (MSE) dengan epoch. Epoch merupakan jumlah iterasi yang dilakukan atau dihasilkan dari proses pelatihan. Hasil dari pelatihan ditunjukkan dengan warna biru, hasil validasi ditunjukkan dengan warna hijau, hasil test ditunjukkan dengan warna merah, dan nilai best atau nilai terbaik dari hasil performance ditunjukkan dengan garis titiktitik. Hasil performance terbaik pada proses pelatihan gangguan satu phasa ke tanah diperoleh pada saat epoch ke 7 dari 13 epoch dengan nilai best validation performance 1017476.8012. Grafik performance pada proses pelatihan gangguan satu phasa ke tanah dapat dilihat dalam gambar 18. 


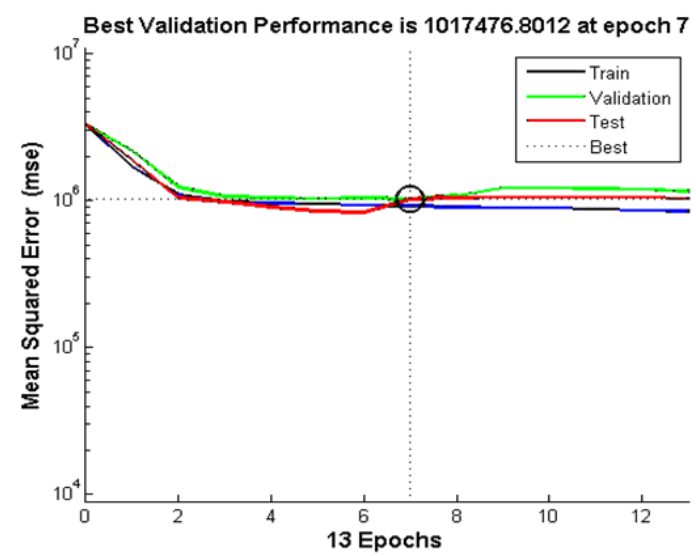

Gambar 18: Hasil performance pada saat gangguan satu phasa ke tanah

\section{F. Proses Pelatihan Dengan Metode Jaring syaraf tiruan Pada Saat Gangguan Antar phasa ke Tanah}

Proses pelatihan gangguan antar phasa ke tanah pada jaringan transmisi menggunakan metode jaring syaraf tiruan, gangguan yang terjadi diatur pada phasa A dan phasa B, hasilnya kemudian dianalisa sebagai berikut.

Grafik performance pada proses pelatihan gangguan antar phasa ke tanah diperoleh dari hasil perbandingan antara nilai mean squared error (MSE) dengan epoch. Epoch merupakan jumlah iterasi yang dilakukan atau dihasilkan dari proses pelatihan. Hasil dari pelatihan ditunjukkan dengan warna biru, hasil validasi ditunjukkan dengan warna hijau, hasil test ditunjukkan dengan warna merah, dan nilai best atau nilai terbaik dari hasil performance ditunjukkan dengan garis titiktitik. Hasil performance terbaik pada proses pelatihan gangguan antar phasa ke tanah diperoleh pada saat epoch ke 67 dari 73 epoch dengan nilai best validation performance 0.46621. Grafik performance pada proses pelatihan gangguan antar phasa ke tanah dapat dilihat dalam gambar 19.

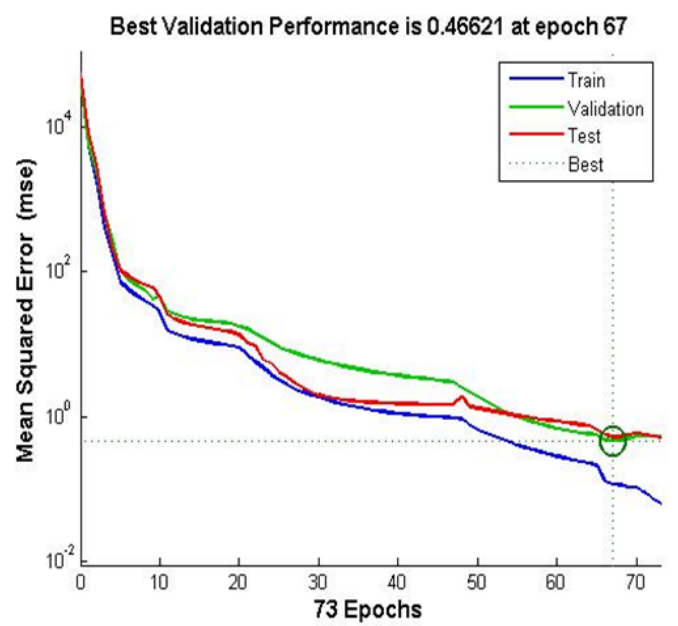

Gambar 19: Hasil performance pada saat gangguan antar ke tanah

\section{G. Proses Pelatihan Dengan Metode Jaring syaraf tiruan Pada Saat Gangguan antar phasa}

Proses pelatihan gangguan antar phasa pada jaringan transmisi menggunakan metode jaring syaraf tiruan, gangguan yang terjadi diatur pada phasa A dan phasa B tanpa di hubungkan ke tanah, dimana hasilnya kemudian dianalisa sebagai berikut.

Grafik performance pada proses pelatihan gangguan antar phasa diperoleh dari hasil perbandingan antara mean squared error (MSE) dengan epoch. Epoch merupakan jumlah iterasi yang dilakukan atau dihasilkan dari proses pelatihan. Hasil dari pelatihan ditunjukkan dengan warna biru, hasil validasi ditunjukkan dengan warna hijau, hasil test ditunjukkan dengan warna merah, dan nilai best dari hasil performance ditunjukkan dengan garis titik-titik. Hasil performance terbaik pada proses pelatihan gangguan antar phasa diperoleh pada saat epoch ke 1 dari 7 epoch dengan nilai best validation performance 57382.6513. Grafik performance pada proses pelatihan gangguan antar phasa dapat dilihat dalam gambar 20.

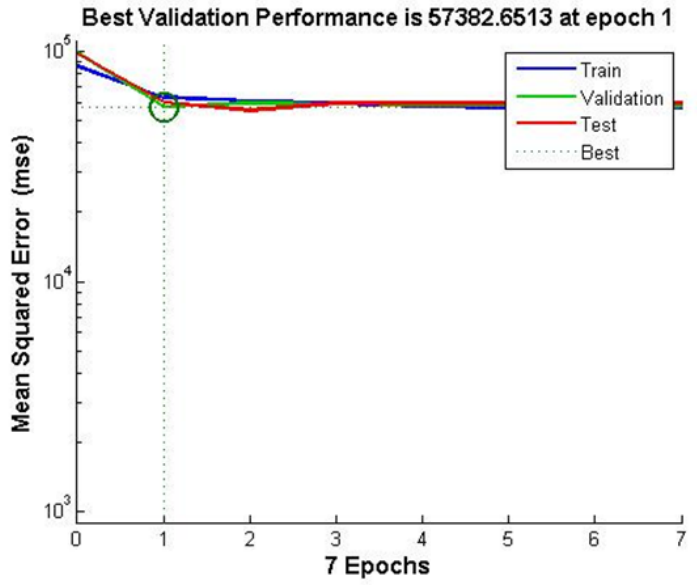

Gambar 20: Hasil performance pada saat gangguan antar phasa

\section{H. Proses Pelatihan Dengan Metode Jaring syaraf tiruan Pada Saat Gangguan simetris}

Proses pelatihan gangguan simetris pada jaringan transmisi menggunakan metode jaring syaraf tiruan, dimana gangguan yang terjadi diatur pada phasa A, phasa B dan phasa C, yang selanjutnya hasilnya dianalisa sebagai berikut.

Grafik performance pada proses pelatihan gangguan simetris diperoleh dari hasil perbandingan antara nilai mean squared error (MSE) dengan epoch. Epoch merupakan jumlah iterasi yang dilakukan atau dihasilkan dari proses pelatihan. Hasil dari pelatihan ditunjukkan dengan warna biru, hasil validasi ditunjukkan dengan warna hijau, hasil test ditunjukkan dengan warna merah, dan nilai best dari hasil performance ditunjukkan dengan garis titik-titik. Hasil performance terbaik pada proses pelatihan gangguan simetris diperoleh pada saat epoch ke 27 dari 33 epoch dengan nilai best validation performance 5.0038 . Grafik performance pada proses pelatihan gangguan simetris dapat dilihat dalam gambar 21.

I Made Widiarsana: Identifikasi Jenis Gangguan pada Jaringan ... 


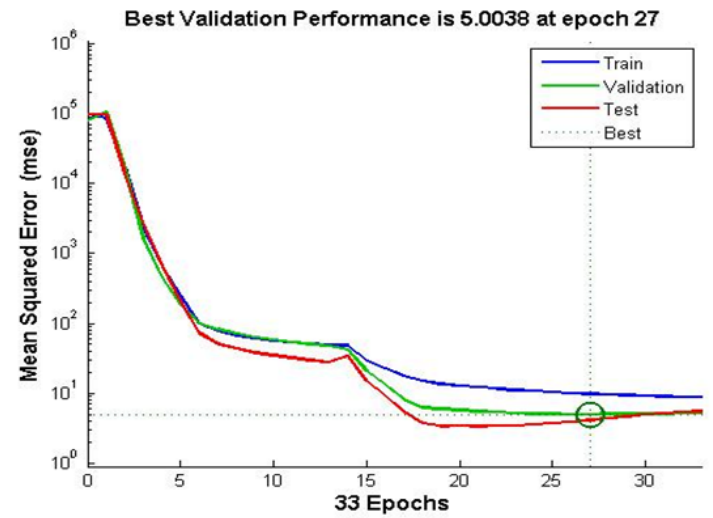

Gambar 21: Hasil performance pada saat gangguan simetris

\section{HASIL PELATIHAN IDENTIFIKASI JENIS GANGGUAN PADA} JARINGAN TRANSMISI MENGGUNAKAN METODE JARING SYARAF TIRUAN

\section{A. Hasil Pelatihan pada saat keadaan normal}

Hasil pelatihan pada saat keadaan normal akan disimpan dan dijadikan sebagai refrensi untuk menentukan keadaan yang terjadi pada jaringan transmisi. Apabila data hasil simulasi mendekati dengan output maka jaringan transmisi berada dalam keadaan normal. Hasil pelatihan yang diperoleh berupa nilai arus dan tegangan pada keadaan normal yang dapat dilihat pada gambar 22 .

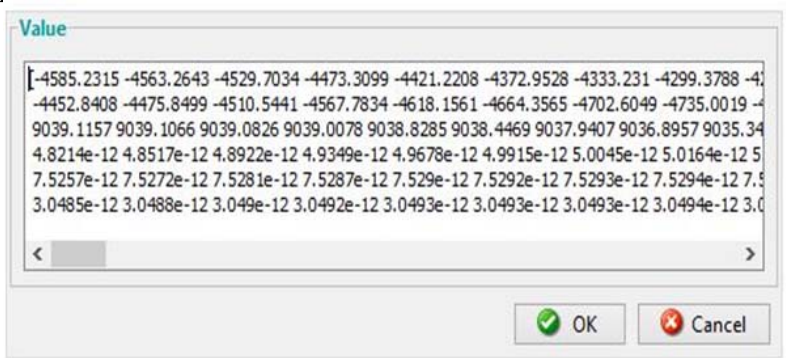

Gambar 22: Hasil pelatihan pada saat keadaan normal

\section{B. Hasil Pelatihan pada saat gangguan satu phasa ke tanah}

Hasil dari proses pelatihan gangguan satu phasa ke tanah yang terjadi pada phasa A menunjukkan nilai tegangan output pada phasa A bernilai nol. Dimana hal ini disebabkan karena pada gangguan satu phasa ke tanah gangguan yang terjadi pada phasa A terhubung langsung dengan tanah. Hasil pelatihan yang diperoleh berupa nilai arus dan tegangan pada saat terjadinya gangguan satu phasa ke tanah yang dapat dilihat pada gambar 23.

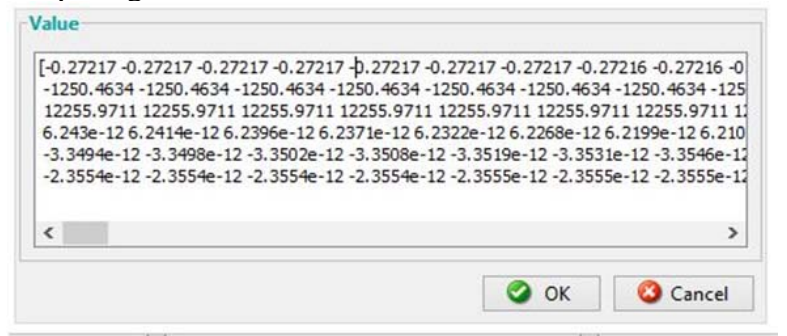

Gambar 23: Hasil pelatihan pada saat gangguan satu phasa ke tanah

\section{Hasil Pelatihan pada saat gangguan antar phasa ke tanah}

Hasil proses pelatihan gangguan antar phasa ke tanah yang terjadi pada phasa A dan phasa B menunjukkan nilai tegangan output pada phasa A dan phasa B bernilai nol. Dimana hal ini disebabkan karena pada gangguan antar phasa ke tanah, phasa yang mengalami gangguan yaitu phasa A dan phasa B terhubung langsung ke tanah. Hasil pelatihan yang diperoleh berupa nilai arus dan tegangan pada saat terjadinya gangguan antar phasa ke tanah yang dapat dilihat pada gambar 24 .

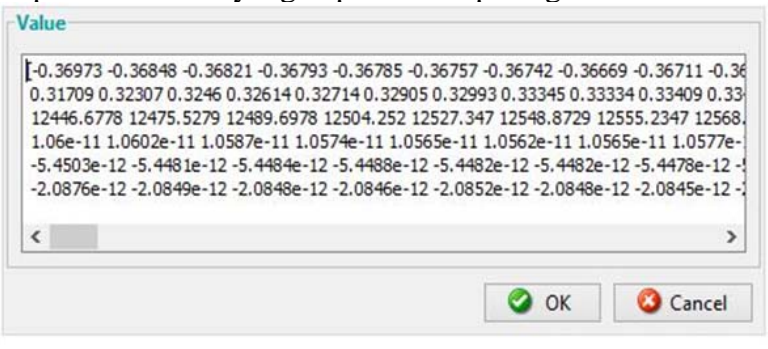

Gambar 24: Hasil pelatihan pada saat gangguan dua phasa ke tanah

\section{Hasil Pelatihan pada saat gangguan antar phasa}

Hasil proses pelatihan gangguan antar phasa yang terjadi pada phasa A dan phasa B menunjukkan nilai tegangan output pada phasa A dan phasa B bernilai hampir sama. Hal ini dikarena gangguan yang terjadi pada phasa A dan phasa B ketika terjadi gangguan antar phasa, phasa A dan phasa B tidak terhubung langsung ke tanah. Hasil pelatihan yang diperoleh berupa nilai arus dan tegangan pada saat terjadi gangguan antar phasa yang dapat dilihat pada gambar 25 .

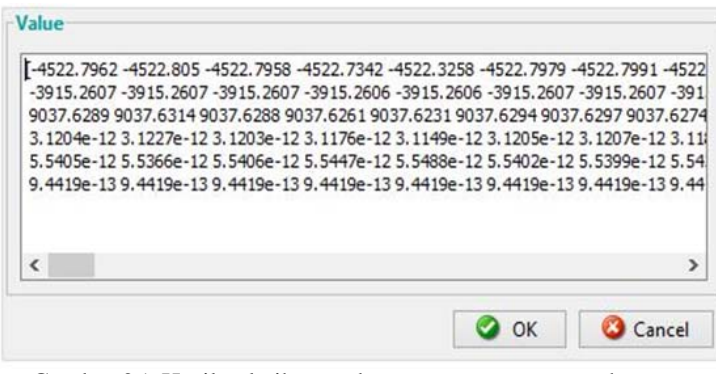

Gambar 25: Hasil pelatihan pada saat gangguan antar phasa

\section{E. Hasil Pelatihan pada saat gangguan simetris}

Hasil proses pelatihan gangguan simetris yang terjadi pada phasa $A$, phasa $B$ dan phasa $C$ menunjukkan nilai tegangan output pada phasa A, phasa B dan phasa C bernilai sama. Hal ini disebabkan karena gangguan simetris merupakan gangguan hubung singkat yang terjadi pada semua phasanya sehingga menyebabkan arus maupun tegangan pada setiap phasanya tetap bernilai seimbang setelah terjadi gangguan. Hasil pelatihan yang diperoleh berupa nilai arus dan tegangan pada saat terjadinya gangguan simetris yang dapat dilihat pada gambar 26. 


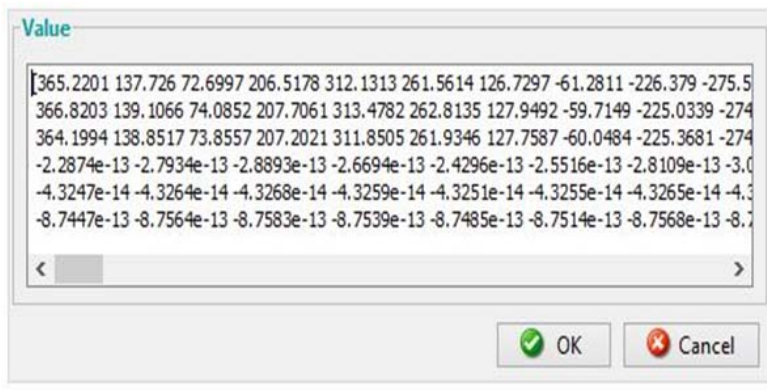

Gambar 26: Hasil pelatihan pada saat gangguan simetris

\section{KESIMPULAN}

Berdasarkan hasil analisa dan hasil pembahasan yang telah dilakukan mengenai identifikasi jenis gangguan pada jaringan transmisi menggunakan jaring syaraf tiruan, maka dapat disimpulkan sebagai berikut:

1. Proses pembangkitan nilai arus dan tegangan gangguan pada saat terjadi gangguan satu phasa ke tanah, antar phasa ke tanah dan gangguan simetris menghasilkan bentuk gelombang tegangan pada phasa yang mengalami gangguan hubung singkat akan bernilai nol, sedangkan untuk gangguan antar phasa menghasilkan bentuk gelombang yang sama pada phasa yang mengalami gangguan. Nilai gelombang arus pada saat terjadi gangguan hubung singkat menunjukkan terjadinya penurunan nilai gelombang secara perlahan.

2. Hasil output dari proses pelatihan identifikasi akan disimpan dan dijadikan sebagai refrensi untuk menentukan keadaan yang terjadi pada jaringan transmisi.

3. Kelebihan dari jaring syaraf tiruan dalam mengidentifikasi jenis gangguan yang terjadi yaitu memiliki kemampuan belajar terhadap kesalahan yang terjadi, bersifat fleksibel terhadap perubahan yang terjadi pada suatu lingkungan, memiliki kemampuan perhitungan secara pararel, dan dapat menyelesaikan suatu permasalahan yang lebih kompleks yang tidak dapat diselesaikan dengan metode konvensional.

\section{REFERENSI}

[1] Singh, S., Mamatha, K.R., Thejaswini, S. 2014. Intelligent Fault Identification Sistem for Transmission Lines Using Artificial Neural Network. IOSR Journal of Computer Engineering. 16: 24-30.

[2] Sonali, Ms., Maind, B., Wankar, P. 2014. Research Paper on Basic of Artificial Neural Network. International Journal on Recent and Inovation Trends in Computing and Communication. 2: 96

[3] Kencana, I. P. E. N. 2012. Evaluasi Kinerja Jaringan Syaraf Tiruan pada Peramalan Konsumsi Listrik Kelompok Tarif Rumah Tangga. Laboratorium Komputasi Jurusan FMIPA UNUD, Vol 2 (Juni) : 10.

[4] Nordiansyah, M., Arjana, I. G. D., Setiawan, W. 2014. Setting Rele Jarak pada Sistem SUTT 150 KV GI Kapal - GI Padang Sambian Menggunakan Metode Adaptive Neuro - Fuzzy Inference Sistem (ANFIS) . Teknik Elektro, Vol 1 (Desember) : 85.

[5] Sau, M. 2015. Transmisi Daya Listrik Dilengkapi Dengan Contoh Soal Matlab, edisi satu. Yogyakarta: ANDI.

[6] Mardensyah, A. 2008. Studi Perencanaan Koordinasi Sistem Proteksi. Fakultas Teknik Universitas Indonesia, Jakarta.

[7] Hadianto, A. B., Arjana, I. G. D., Setiawan, W. 2016. Study Perhitungan Relay Jarak pada Saluran Double Circuit dengan Single Conductor antara GI Kapal - GI Pemecutan Kelod Menggunakan Artificial Neural Network (ANN). Teknik Elektro, Vol 15 ( Juli Desember ) : 60-61

[8] Sudarsono, A. 2016. Jaringan Syaraf Tiruan untuk Memprediksi Laju Pertumbuhan Penduduk Menggunakan Metode Backpropagation (Studi Kasus di Kota Bengkulu). Jurnal Media Infotama. 12: 61.

[9] Hermawan, A. 2006. Jaringan Syaraf Tiruan Teori dan Aplikasi, edisi satu. Jogyakarta: ANDI.

[10] Kesharwani, S., Singh, D., K. 2014. Simulation Of Fault Detection For Protection Of Transmission Line Using Neural Network. International Journal of Science, Engineering and Technology (IJSETR), Vol 3 (May) 